\title{
Idiopathic (primary) achalasia: a review
}

\author{
Dhyanesh A. Patel ${ }^{1}$, Hannah P. Kim ${ }^{1}$, Jerry S. Zifodya ${ }^{1}$ and Michael F. Vaezi ${ }^{2 *}$
}

\begin{abstract}
Idiopathic achalasia is a primary esophageal motor disorder characterized by loss of esophageal peristalsis and insufficient lower esophageal sphincter relaxation in response to deglutition. Patients with achalasia commonly complain of dysphagia to solids and liquids, bland regurgitation often unresponsive to an adequate trial of proton pump inhibitor, and chest pain. Weight loss is present in many, but not all patients. Although the precise etiology is unknown, it is often thought to be either autoimmune, viral immune, or neurodegenerative. The diagnosis is based on history of the disease, barium esophagogram, and esophageal motility testing. Endoscopic assessment of the gastroesophageal junction and gastric cardia is necessary to rule out malignancy. Newer diagnostic modalities such as high resolution manometry help in predicting treatment response in achalasia based on esophageal pressure topography patterns identifying three phenotypes of achalasia (I-III) and outcome studies suggest better treatment response with types I and II compared to type III. Although achalasia cannot be permanently cured, excellent outcomes are achieved in over $90 \%$ of patients. Current medical and surgical therapeutic options (pneumatic dilation, endoscopic and surgical myotomy, and pharmacologic agents) aim at reducing the LES pressure and facilitating esophageal emptying by gravity and hydrostatic pressure of retained food and liquids. Either graded pneumatic dilatation or laparoscopic surgical myotomy with a partial fundoplication are recommended as initial therapy guided by patient age, gender, preference, and local institutional expertise. The prognosis in achalasia patients is excellent. Most patients who are appropriately treated have a normal life expectancy but the disease does recur and the patient may need intermittent treatment.
\end{abstract}

Keywords: Esophagus, Achalasia, Motility disorder, Endoscopic balloon dilatation, Laparoscopic surgery

\section{Definition and epidemiology}

Idiopathic achalasia (ORPHA930) is a primary esophageal motility disorder of unknown etiology characterized manometrically by esophageal aperistalsis and insufficient relaxation of the lower esophageal sphincter (LES) in response to deglutition [1-5]. It is a rare disease with an annual incidence of approximately $2 / 100,000$ and a prevalence rate of 10/100,000 [6]. Studies have shown that incidence and prevalence of the disease are increasing $[7,8]$ and the peak incidence occurs between 30 and 60 years of age [7]. Achalasia was first described and termed by Sir Thomas Willis in 1674, when he suggested that the disease is due to the loss of normal inhibition in the distal esophagus [9]. Since then, the development of new diagnostic techniques stimulated new ideas about the etiology and pathophysiology of the disease leading

\footnotetext{
* Correspondence: Michael.vaezi@vanderbilt.edu

${ }^{2}$ Division of Gastroenterology, Hepatology and Nutrition, Vanderbilt University Medical Center, Nashville, TN, USA

Full list of author information is available at the end of the article
}

to various theories in identifying the nature of motor disturbances in esophageal regions. However, the initiating cause is still unclear $[3,9,10]$.

In this review article we provide current insight on the pathogenesis, etiology, diagnosis, and treatment options for this motor disorder of the esophagus.

\section{Clinical description}

Achalasia is one of the most investigated motor disorders of the esophagus $[4,10]$. The disease can occur at any age but it is usually diagnosed between 30 and 60 years. Progressive dysphagia to solids followed by liquids ( $82 \%-100 \%)$ is the first clinical symptom of achalasia [11]. Although dysphagia can occur in patients with other esophageal motility disorders, this symptom is most characteristic of achalasia and strongly suggests the diagnosis.

Regurgitation not responding to adequate proton pump inhibitor (PPI) therapy and weight loss can be seen in $30 \%$ to $90 \%$ of patients. Regurgitation of
C Biomed Central (c) 2015 Patel et al. This is an Open Access article distributed under the terms of the Creative Commons Attribution License (http://creativecommons.org/licenses/by/4.0), which permits unrestricted use, distribution, and reproduction in any medium, provided the original work is properly credited. The Creative Commons Public Domain Dedication waiver (http:// creativecommons.org/publicdomain/zero/1.0/) applies to the data made available in this article, unless otherwise stated. 
material retained in the dilated esophagus, especially during supine position at night, may lead to aspiration. There is no universal definition for "adequate" PPI therapy, however, based on recent gastro-esophageal reflux disease (GERD) guidelines, it has been taken to constitute ensuring compliance, optimal dosing, changing to a different PPI, and possibly BID dosing [12]. Chest pain is another presenting symptom of achalasia (17 \%-95 \%). The occurrence of this symptom is unrelated to the LES pressure $[4,11]$. Chest pain has been found to be more frequent in younger patients and in female patients who have achalasia [4, 13-15]. In addition, $40 \%$ of patients with achalasia report occurrence of at least one respiratory symptom daily, including cough (37 \%), hoarseness (21\%), wheezing (15\%), shortness of breath (10\%), and sore throat (12\%) [16].

Heartburn, the main symptom of GERD, may also occur infrequently (27\%-42\%) in achalasia patients. The mean LES pressure in patients with achalasia who experience heartburn has been reported to be significantly lower than that in patients without heartburn [17]. Weight loss (usually between 5 and $10 \mathrm{~kg}$ ) is present in most but not all patients. Difficulty belching has also been reported in up to $85 \%$ of the patients, and is due to a defect in relaxation of the upper esophageal sphincter in these patients $[1,18]$.

\section{Etiology}

The distal esophageal wall and LES are innervated by postganglionic neurons, consisting of excitatory and inhibitory neurons. The excitatory neurons release acetylcholine while the inhibitory neurons release nitric oxide (NO) and vasoactive intestinal polypeptide (VIP), resulting in esophageal and LES contractions and relaxations, respectively [3]. The NO and VIP releasing inhibitory neurons are the target in idiopathic achalasia. Loss of these inhibitory neurons due to either intrinsic or extrinsic causes will result in the manometric consequence of failure of LES relaxation and loss of esophageal peristalsis $[3,4,19]$.

Several studies on humans and animals $[20,21]$ have suggested that extrinsic causes such as lesions located in the central nervous system (CNS) may produce manometric findings of achalasia. Abnormalities of the vagal nerve fibers outside the CNS has also been associated with achalasia; however, extrinsic innervation abnormalities are rare findings in achalasia patients [22-24] and are thus probably not the primary mechanism of the disease. In contrast, intrinsic loss of inhibitory myenteric neurons in both the esophagus and LES has been reported as the most likely contributory factor in the pathophysiology of achalasia. Studies [25-27] have suggested that loss of VIP and NO secreting neurons leads to an imbalance between the excitatory and inhibitory neurons of the myenteric plexus, producing irreversible manometric changes in such patients. Morphologic studies of the esophageal myenteric plexus have also confirmed the loss of myenteric ganglion cells in achalasia $[28,29]$. In such studies, loss of ganglion cells was associated with inflammation and in severe cases, the myenteric nerves had been replaced by collagen.

\section{Genetic}

The existence of familial cases suggest that achalasia is an inherited disease [30-33]. Such familial cases have been mostly seen in the pediatric population, between siblings and in a few cases in monozygotic twins [30,31]. Achalasia has been associated with Allgrove (Triple-A) syndrome, Down's syndrome, and congenital central hypoventilation syndrome [34].

Mutation of the ALADIN 12q13 gene is a commonly reported cause of achalasia in children. It leads to the development of Allgrove syndrome, also known as Triple-A syndrome, which is an autosomal disease characterized by adrenocorticotropin hormone (ACTH) resistant adrenal insufficiency, achalasia, and alacrima [35]. Furthermore, $77 \%$ of children with Down's syndrome have gastrointestinal abnormalities with $2 \%$ developing achalasia [36]. Recent studies have also shown multiple genetic mutations such as nitric oxide synthase 1 gene (NOS1), VIP receptor 1, IL23R, IL10 promoter, IL33, and protein tyrosine phosphatase non-receptor 22 (PTPN22) to be associated with the development of achalasia [37-43]. It is proposed that genetic predisposition in such individuals probably increases their susceptibility to acquiring achalasia after exposure to common environmental factors that may play a role in the pathogenesis [2].

\section{Infection}

Several studies have suggested a possible association between viral infections and achalasia [44, 45]. In these studies, various viral antibodies were measured in the serum of patients with achalasia and in normal controls. Measles and varicella zoster virus antibodies were found to be higher among a number of patients with achalasia [3]. Studies using polymerase chain reaction (PCR) demonstrated no evidence of viral products in esophageal tissue of patients with achalasia [46, 47]. More recently, Castaglinolo et al. demonstrated HSV-1 reactive immune cells in LES muscles of patients with achalasia [48]. Though HSV-1 may be also found in patients' without achalasia, the presence of these immune reactive cells directed at the virus suggests HSV-1 may play a role in genetically susceptible individuals. A role for HSV-1 was further demonstrated by Facco et al. who demonstrated increased $\mathrm{T}$ cell proliferation and $\mathrm{T}$ helper-1 type cytokines release in response to HSV-1 
antigen from LES muscle specimens harvested during laparoscopic myotomy of 59 patients with idiopathic achalasia [49]. Thus, although the infectious etiology of achalasia remains an unclear matter, there is mounting evidence suggesting an immune-mediated inflammatory disease in which latent HSV-1 infection leads to persistent immune activation and eventual self-destruction of esophageal neurons in genetically susceptible patients [50].

\section{Autoimmune}

Increased prevalence of circulating antibodies against myenteric plexus in some patients with achalasia led to the suggestion of a role for auto-antibodies in the pathogenesis of this disease [51, 52]; however, a recent study by Moses et al. [53] suggested that these circulatory antibodies are most likely the result of a nonspecific reaction to the disease process instead of being the cause of the disease. This idea was supported by detection of similar antibodies in patients without achalasia. A recent study did find that patients with achalasia were $3.6 \times$ more likely to have autoimmune diseases including Sjogren's syndrome, uveitis, systemic lupus erythematosus, type I diabetes, and hypothyroidism [54].

Ultra-structural studies $[55,56]$ of the esophageal tissue of patients with achalasia have also found inflammatory infiltrates around myenteric neurons, while in control groups normal myenteric plexus was found without infiltration. Multiple case-control studies [57-60] have reported a significant association with HLA class II antigens in idiopathic achalasia. A recent study [60] also showed that achalasia patients with the associated HLA allele had a higher prevalence of circulating anti-myenteric autoantibodies, which supports the autoimmune etiology theory [3]. HLA association also suggests immunogenetic predisposition for idiopathic achalasia.

Overall, etiology behind the development of achalasia is likely multifactorial and continues to be highly investigated. Several genes and autoimmune disorders have been associated with achalasia as outlined above. It is proposed that genetic predisposition probably increases the likelihood of triggering autoimmune mechanisms after exposure to viruses or other common environmental factors [61].

\section{Diagnosis}

The diagnosis of idiopathic achalasia is relatively straightforward with a well-documented medical history, radiography, and esophageal motility testing.

\section{History}

In the early stages of the disease, dysphagia may be very subtle and can be misinterpreted as dyspepsia, poor gastric emptying, or stress. The presence of heartburn due to food stasis can add to this confusion. As the disease progresses, difficulty swallowing characteristically occurs with both solids and liquids and is often associated with regurgitation of bland undigested food or saliva [5]. The dysphagia is more to solids than liquids. To ease progression of the food bolus, patients usually modify their eating habits: eating more slowly or using certain maneuvers such as raising the arms or arching the back.

\section{Esophageal manometry}

Manometry is the gold standard for establishing the diagnosis of achalasia and is essential for the diagnosis regardless of the findings on barium esophagram and esophagogastroduodenoscopy (EGD). The manometric findings of aperistalsis and incomplete LES relaxation is characteristic on conventional manometry. Wet and dry swallows are followed by simultaneous contractions [1]. The amplitude of the contractions is low (10-40 mm $\mathrm{Hg}$ ) and repetitive in most cases [9] (Fig. 1). The LES displays high pressure at rest and fails to relax, or relaxes only partially with swallowing (Fig. 1). Up to $40 \%$ of the patients with achalasia have normal LES pressure $(10-40 \mathrm{~mm} \mathrm{Hg})$; however, low pressure LES is not seen in untreated achalasia patients [62].

Aperistalsis is defined as lack of propagating esophageal contractile activity and presents with different pressure patterns including quiescent esophageal body (Type I), isobaric pan-esophageal pressurization (Type II), or simultaneous contractions (Type III), and can now be easily identified with high-resolution manometry (HRM) (Fig. 2) [63]. Although both conventional manometry or HRM can be used for diagnosis, new data is emerging to suggest that HRM may have increased sensitivity in diagnosing achalasia compared to conventional manometry techniques [64]. More importantly, new space-time analysis paradigms with HRM that portrays the pressure signal through the esophagus in a seamless dynamic space-time continuum in the form of esophageal pressure topography can help characterize the motor patterns with treatment outcome implications. Based on three retrospective studies, subtype II has the best prognosis, whereas subtype I is somewhat lower and subtype III can be difficult to treat $[63,65,66]$.

\section{Timed barium esophagogram}

Barium swallow was initially used by Vantrappen et al. [67] in achalasia patients to determine the cause of persistent symptoms after treatment with pneumatic dilation. The characteristics of achalasia in barium esophagogram are the loss of primary peristalsis in the distal two third of the esophagus, and poor emptying with retained food and saliva producing an air-fluid level at the top of the barium column. In chronic stages of the disease, there is a dilated esophagus or sigmoid tortuosity and sometimes, in advanced cases, massive 


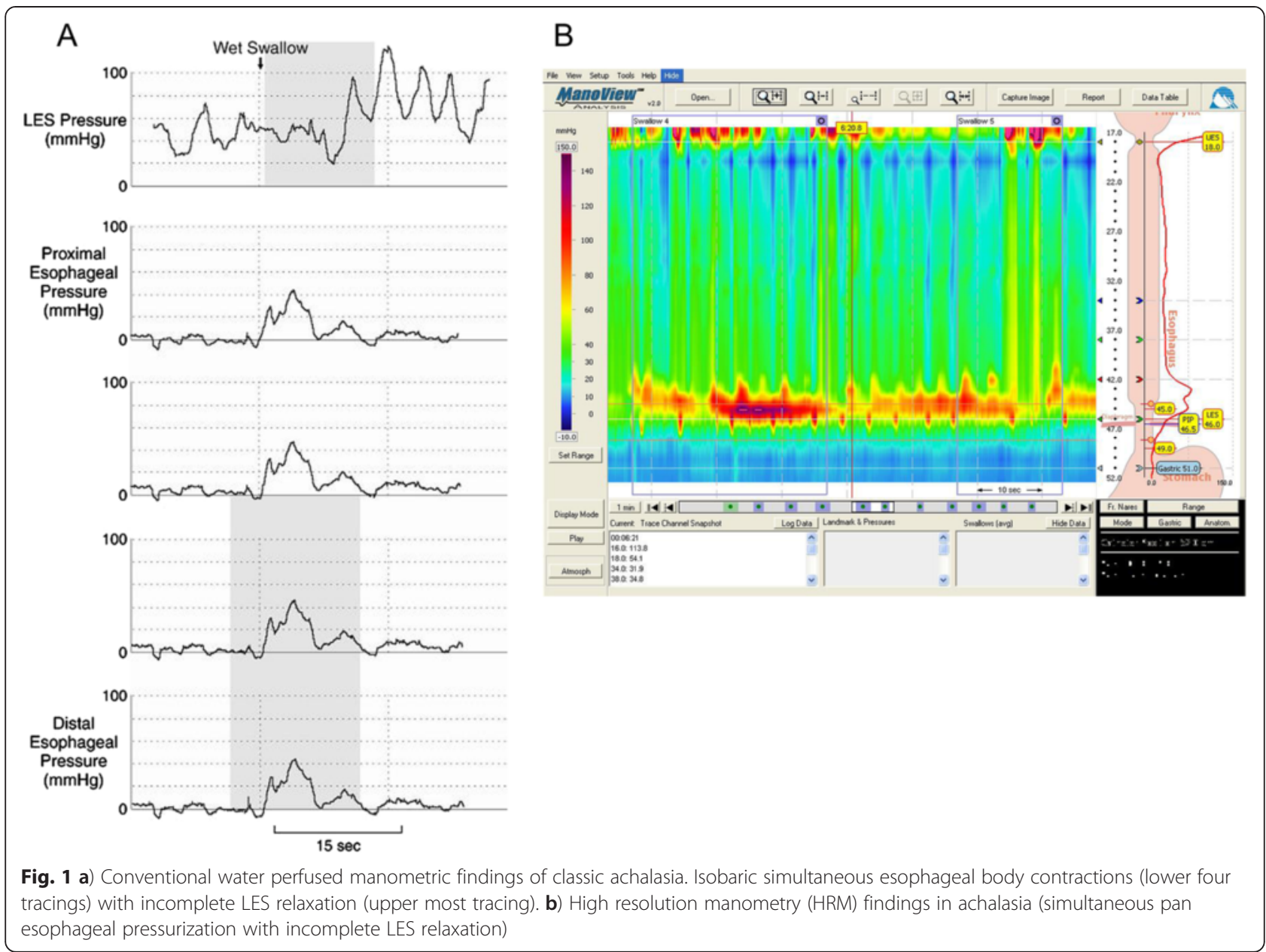

dilatation of the esophageal body that have implications for treatment $[1,5]$. The typical finding in achalasia is the presence of smooth tapering of the lower esophagus leading to a closed LES, resembling a bird's beak (Fig. 3).

In 1997 de Oliveira et al. [68] described timed barium esophagogram as a simple, noninvasive, and widely available barium technique for evaluating esophageal emptying in patients with achalasia, which can provide objective assessment after therapy as in many patients with achalasia, symptom relief does not always parallel esophageal emptying. The films in this technique are taken at 1,2 and 5 minutes after the last swallow of barium; the purpose of $2 \mathrm{~min}$ film is to assess interim emptying (Fig. 4). The technique is simple to interpret because both radiologists and gastroenterologists can accurately assess emptying. Emptying can be assessed by the height time width of the barium column or a qualitative estimate of emptying. This method can be also used in predicting the success of treatment in patients with achalasia, which will be discussed later [68-71].

\section{Endoscopy}

All patients with suspected achalasia should undergo upper gastrointestinal endoscopy to exclude mechanical obstruction or pseudoachalasia that can mimic achalasia both clinically and manometrically [72, 73]. Pseudoachalasia results from a tumor at the esophagogastric junction, therefore, this area needs to be examined carefully during the procedure $[1,3]$. At endoscopy, the esophageal body may look normal, or dilated, atonic and often tortuous. The mucosa looks normal, but sometimes it is thickened or friable with even superficial ulcers secondary to chronic stasis or candida esophagitis. The LES is closed even with insufflations of air, but the endoscope can easily pass this area with gentle pressure. If a tumor is suspected because of rapid progression of symptoms, or the need of excess pressure to open the LES, repeated endoscopy examinations with biopsies and endoscopic ultrasound and CT chest are mandatory. A study by Mittal et al. (2003), also showed that endoscopic ultrasound may be helpful in further evaluation of the LES and ruling out infiltrating tumor if there is stronger resistance on endoscopic evaluation [74]. 


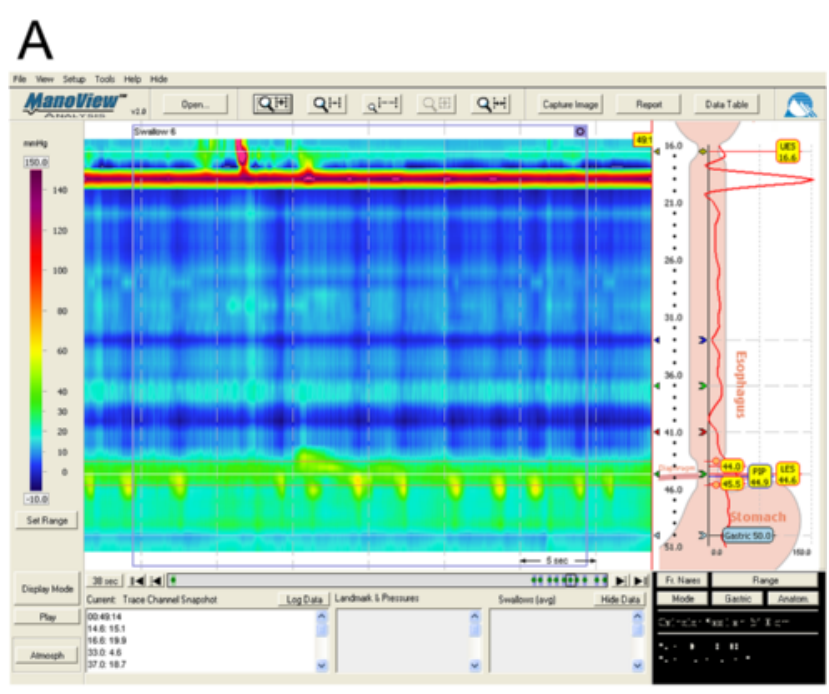

\section{B}
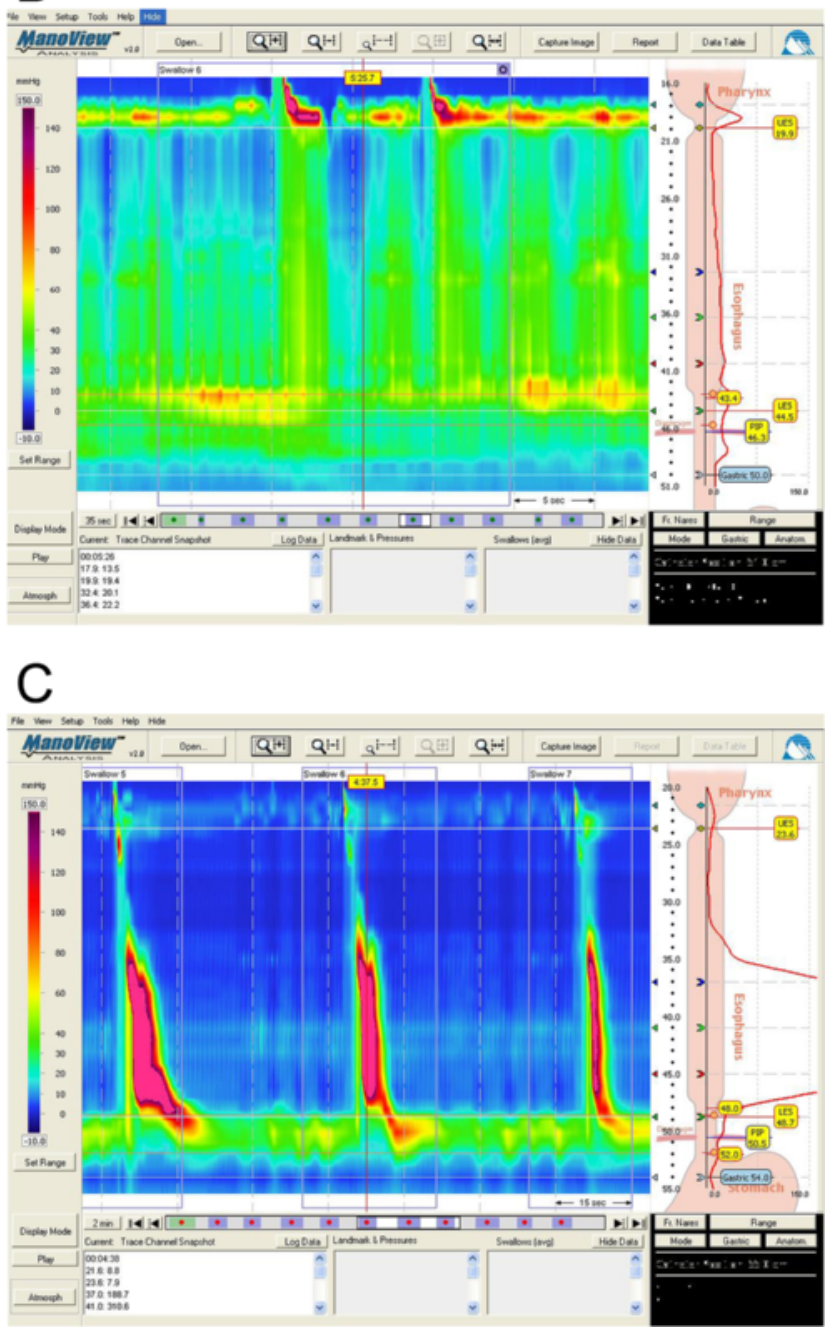

Fig. 2 Three sub-types of achalasia on high resolution manometry. a Quiescent esophageal body (Type I); b isobaric pan-esophageal pressurization (Type II); c simultaneous contractions (Type III) 


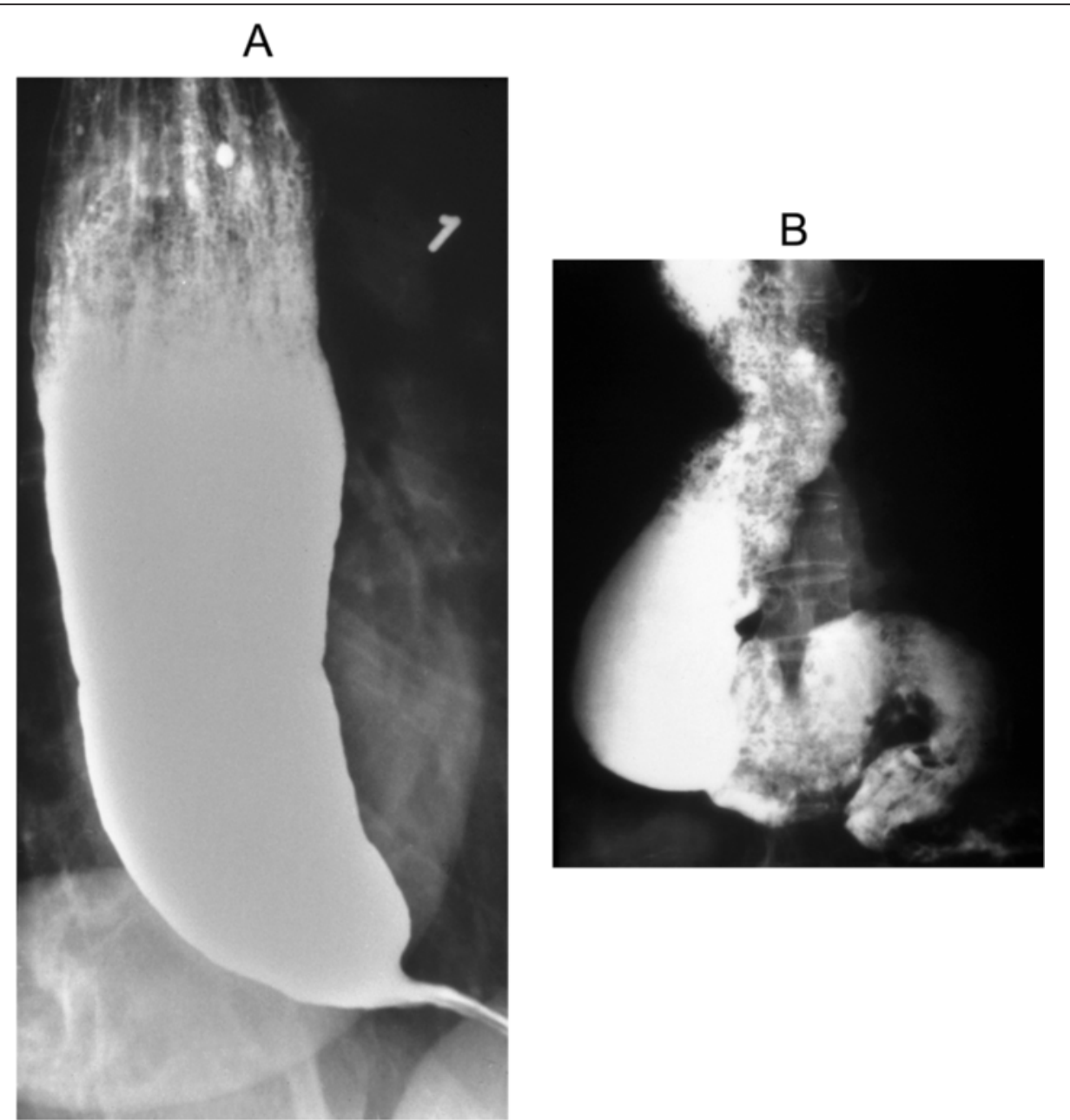

Fig. 3 Barium swallow. a Dilated esophagus with retained column of barium and "bird's beaking" suggestive of achalasia. b End stage achalasia with retained food, barium and tortuous esophagus

Although esophageal biopsies are recommended in patients undergoing endoscopic evaluation for dysphagia to assess for eosinophilic esophagitis, biopsies are generally not necessary if the endoscopic findings are characteristic for achalasia [5]. However, it is important to note that it is not uncommon to find an increased number of eosinophils in patients with achalasia secondary to potential stasis inflammation [28, 75], and clinical presentation and classic manometric findings might be necessary to help distinguish the two diagnoses. The information on cancer risk in achalasia is insufficient. There are many studies on this and the great majority of them suggests a significantly increased risk [76]; however, there are currently no recommendations for surveillance of achalasia patients for esophageal cancer.

\section{Differential diagnosis}

A majority of patients are misdiagnosed as having reflux disease given regurgitation. The differential diagnosis of a patient with dysphagia and regurgitation includes
GERD, pseudoachalasia (associated with malignancies or secondary achalasia from extrinsic processes such as prior tight fundoplication), iatrogenic achalasia (obstructive procedures for weight loss) and possibly eosinophilic esophagitis. Tumors in the gastric cardia or those infiltrating the myenteric plexus (adenocarcinoma of the gastroesophageal junction, pancreatic, breast, lung, or hepatocellular cancers) should be considered highly in the differential based on findings on EGD and manometry and if the clinical history is significant for acute weight loss [72]. Infection by Trypanosoma Cruzi, also known as Chagas' disease, can also result in achalasia, but these patients often have other features of diffuse enteric myenteric destruction, including megacolon, heart disease, and neurologic disorders [77].

\section{Management}

Despite insight into the pathophysiology of achalasia, the etiology of the disorder remains unknown; thus, it 

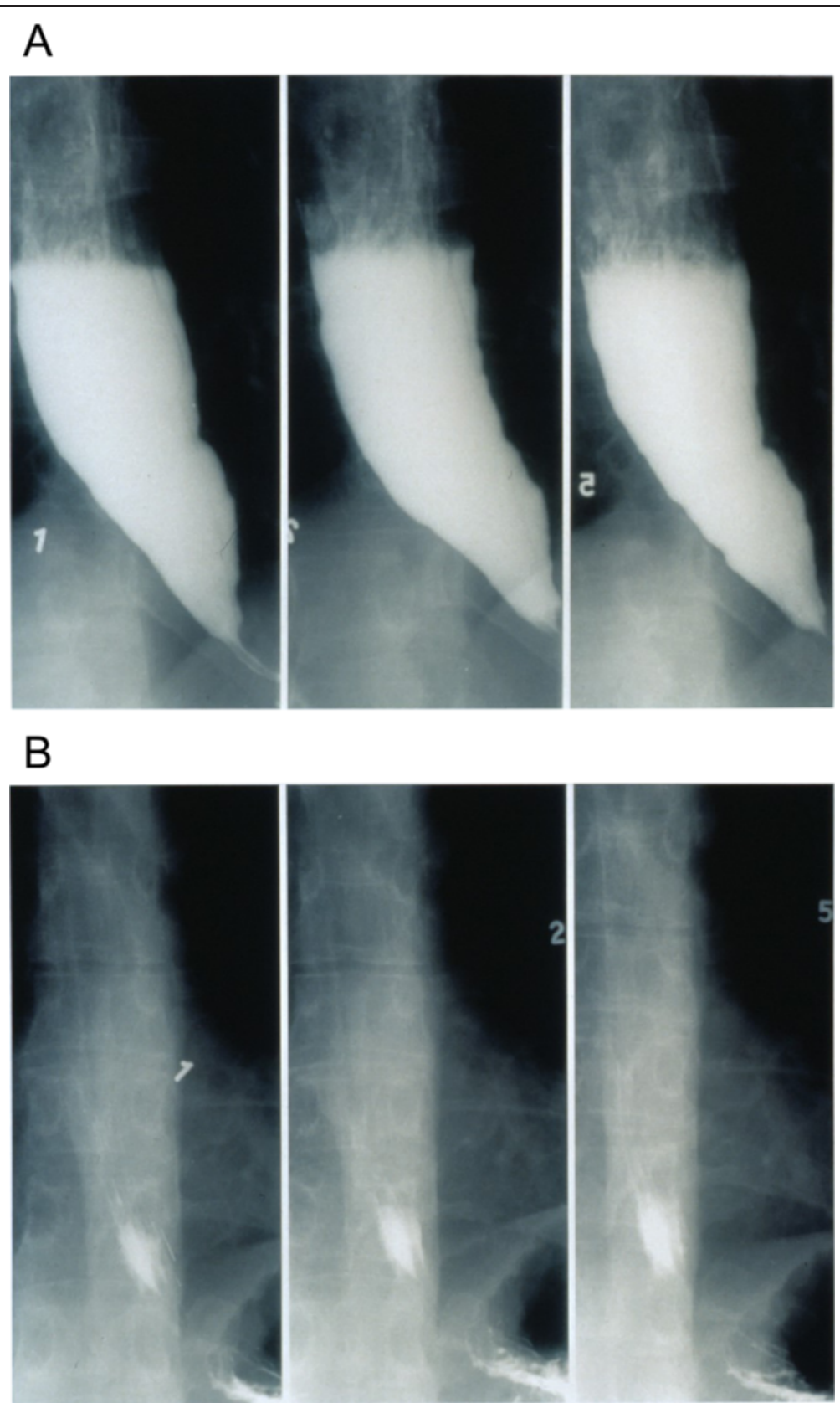

Fig. 4 Timed barium swallow before and after pneumatic dilation showing retention of barium in the former and complete emptying post effective therapy in the latter

is not surprising that the treatment is entirely palliative. If untreated, the disease course leads to a progressive stasis and dilation of the esophagus, which results in increased risk of aspiration, weight loss, and malnutrition. Current therapeutic options aim to reduce LES pressure, relieve functional obstruction to esophageal transit, and facilitate esophageal emptying. Well-studied treatment options include oral pharmacologic agents, chemical denervation by endoscopic injection of botulinum toxin, pneumatic dilation, and surgical myotomy. More recently investigated endoscopic interventions include self-expanding metallic stents and per-oral endoscopic myotomy (POEM) [78-80]. These methods vary in their level of invasiveness and risk of adverse effects [81, 82].

\section{Pharmacologic treatment}

Oral pharmacologic therapies aim at relaxation of the smooth muscle to lower LES pressure. Calcium channel blockers and nitrates are the two most common agents 
used [83, 84]. Other less commonly used agents include anti-cholinergics (atropine, dicyclomine, cimetropium, bromide), beta-adrenergic agonists (terbutaline), and theophylline [11]. Calcium channel blockers inhibit calcium entry into the cells, resulting in reduced esophageal muscle contraction and a decrease in LES pressure by 13$49 \%$ [5]. Nifedipine is the most commonly used calcium channel blocker for the treatment of achalasia. It is available in a sublingual formulation with maximum effect seen at 20 to $45 \mathrm{~min}$. Sublingual nifedipine $(10-30 \mathrm{mg})$ should be administered 30-45 min prior to meals and at bedtime [11]. The efficacy of nifedipine largely varies with symptom improvement observed in $0 \%$ to $75 \%$ of patients in clinical trials, but its use is largely limited by side effects reported in up to $30 \%$ of patients $[11,81]$.

Nitrates work by increasing NO concentration in smooth muscle cells via cyclic GMP. Sublingual isosorbide dinitrate has been shown to reduce LES pressure by $30-65 \%$, resulting in symptom improvement in 53 to $87 \%$ of patients. The effect of nitrates is more rapid than that of nifedipine, but has a shorter duration; thus, sublingual isosorbide dinitrate $(5 \mathrm{mg})$ is commonly administered only 10 to $15 \mathrm{~min}$ before meals [11].

In a study comparing the effect of sublingual nifedipine to sublingual isosorbide dinitrate, both drugs decreased LES pressure, but the effect of nitrate was slightly better than that of nifidipine (65\% vs. $49 \%$ respectively) [84] Oral pharmacologic therapy is the least effective treatment option for achalasia and rarely yields satisfactory longterm symptom relief. Additionally, use is limited by side effects such as headache, orthostasis, and pedal edema [85]. Therefore, this treatment modality is reserved for patients who are not candidates for pneumatic dilation or surgery, have failed botulinum toxin injections, or as a bridge to more effective therapy [11].

\section{Botulinum toxin treatment}

Botulinum toxin (BT) was first used in achalasia patients by Pasricha and his colleagues [2, 86, 87]. This toxin is derived from Clostridium botulinum and causes paralysis of voluntary and involuntary muscles by inhibiting the release of acetylcholine from presynaptic vesicles. Local injection of BT results in chemical denervation of the LES; thus, improving esophageal emptying by counterbalancing the selective loss of inhibitory neurons in the myenteric plexus $[2,81]$. BT A 80-100 Units are injected through a $5-\mathrm{mm}$ sclerotherapy needle into the LES. Aliquots equaling 20 to $25 \mathrm{U}$ of the toxin are injected into each quadrant of the LES. Injection of BT seems to be simple and safe, without carrying any risk of perforation. Complications are minor and include transient chest pain (16-25\%), reflux symptoms $(<5 \%)$, and rare complications such as mediastinitis and allergic reactions related to egg protein $[5,88]$. There is also concern that repeated BT injections can induce an inflammatory reaction that may obscure the mucosalmuscular plane and increase surgical complications during future surgical myotomy [82, 89-91].

Although initial symptom relief is observed in $>75 \%$ of patients, the therapeutic effect wears off, and approximately $50 \%$ of patients will require repeat injections at 6 to 24 month intervals, or additional treatment with pneumatic dilation (PD) or myotomy [1, 2, 87, 92]. Table 1 reflects the symptom response rate as well as percent of LES pressure drop after treatment with BT over a period of 12 months in most valuable studies. Only a few studies are available on the long-term efficacy of BT. Our initial randomized trial found a one year success rate of $32 \%$ in achalasia patients treated with BT [2]. Annese et al. [93] reported a success rate of $68 \%$ at 24 months after receiving repeated BT injection, while Pasricha et al. [94] found a $30 \%$ efficacy rate after a mean follow-up of 2 years. Post-treatment evaluations have revealed that neither pretreatment LES pressure, amplitude of esophageal contractions, nor duration of illness could be used to predict the outcome of BT injection. Instead, young age and male gender were found to adversely affect the outcome [94, 95]. Symptom relief was found to last up to 1 to 2 years with a single injection in the elderly $[96,97]$. Overall, BT is recommended to be most effective in elderly patients, in whom dilation or surgery represent a high risk.

\section{Pneumatic dilation}

Pneumatic dilation (PD) is the most effective nonsurgical treatment option for patients with achalasia [9]. It uses air to dilate the esophageal lumen and disrupt the circular muscle fibers of the LES [1]. The most commonly used balloon is the Rigiflex dilator. Rigiflex balloons come in three different diameters (3.0, 3.5, and $4.0 \mathrm{~cm}$ ). Initial dilation with a $3.0 \mathrm{~cm}$ balloon is recommended for most patients. The pressure required is usually $8-15$ psi of air held for $15-60 \mathrm{~s}$. The number of dilation sessions depends on recurrence of symptoms and there are scoring systems available such as the Eckardt score system, which can be used to define patient's response to PD [98]. Patients undergo a post-procedure gastrograffin study followed by barium esophagram to rule out esophageal perforation [5].

Cumulatively, dilation with $3.0,3.5$, and $4.0 \mathrm{~cm}$ balloon diameters results in good to excellent symptomatic relief in $74 \%, 86 \%$, and $90 \%$ of treated patients, respectively, with an average follow-up of 1.6 years [11]. Patients often require repeat intervention over time due to decreased remission rates. In a study of 106 patients, Vela et al. reported the success rate of single PD as $62 \%$ at 6 months and $28 \%$ at 6 years, compared to $90 \%$ at 
Table 1 Effect of botulinum toxin on achalasia

\begin{tabular}{|c|c|c|c|c|c|c|}
\hline Study & Method & $\begin{array}{l}\text { Number of patients } \\
\text { enrolled }\end{array}$ & $\begin{array}{l}\% \text { LES pressure decreased } \\
\text { post treatment }\end{array}$ & $\begin{array}{l}\text { Remission rate } \\
\text { at } 1 \text { months }\end{array}$ & $\begin{array}{l}\text { Remission rate } \\
\text { at } 6 \text { months }\end{array}$ & $\begin{array}{l}\text { Remission rate } \\
\text { at } 12 \text { months }\end{array}$ \\
\hline Pasricha et al. [87] & Randomized control trial & 21 & $33 \%$ & $90 \%$ & $44 \%$ & 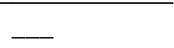 \\
\hline Fishman et al. [92] & Prospective study & 60 & - & $70 \%$ & - & $36 \%$ \\
\hline Gordon et al. [123] & Prospective study & 16 & - & $75 \%$ & $48 \%$ & - \\
\hline Vaezi et al. [2] & Randomized trial & 24 & $1 \%$ & $60 \%$ & $50 \%$ & $32 \%$ \\
\hline Annese et al. [116] & Randomized trial & 16 & $49 \%$ & $100 \%$ & - & $12.5 \%$ \\
\hline Pasricha et al. [94] & Prospective study & 31 & $45 \%$ & $90 \%$ & $64 \%$ & - \\
\hline Martinek et al. [124] & Prospective cohort study & 49 & $65 \%$ & $93 \%$ & - & $41 \%$ \\
\hline Zaninotto et al. [125] & Randomized controlled trial & 40 & - & - & $66 \%$ & $34 \%$ \\
\hline
\end{tabular}

6 months and $44 \%$ at 6 years with serial dilation [99]. In a prospective study, Eckardt et al. treated 54 patients with PD and reported an overall 5-year remission rate of $40 \%$ and a 10-year remission rate of $36 \%$ [95]. Other studies have shown good to excellent symptom improvement in 50-89\% of patients over a mean follow-up of 4 years [11, 100, 101].

Predictors of favorable clinical response to PD include older age ( $>45$ years), female gender, narrow esophagus, LES pressure after dilation of $<10 \mathrm{mmHg}$, increased emptying on post-treatment timed barium esophagram, and type II pattern on HRM. In younger males, it is recommended that the PD employing the $3.5 \mathrm{~cm}$ balloon or surgical myotomy may be the best initial approach $[5,99]$. Pneumatic dilation is well-tolerated with a rare but serious complication of esophageal perforation in approximately $2 \%$ of procedures [11]. Due to the risk of esophageal perforation, patients being considered for PD must be surgical candidates in case of perforation.

Our recent studies [69, 70, 100, 102] suggest timed barium esophagogram as a better predictor of treatment success after PD. We have found that in almost $70 \%$ of the patients, the height of the barium column at $5 \mathrm{~min}$ post-therapy correlates with symptom improvement (concordant group), while in others esophageal emptying was poor despite reports of excellent symptom relief (discordant group). Nearly all patients in discordant group failed the treatment within 1 year after treatment, while $77 \%$ of the concordant group were still in symptom remission after 6 years of follow-up [69]. Therefore, it is suggested that the timed barium esophagogram not only assesses treatment shortly after therapy, it can also predict the poor response to the treatment if the patient has retained barium post-pneumatic dilation.

\section{Surgical myotomy}

Surgical management of achalasia involves performing a Heller myotomy (HM), combined with a fundoplication to prevent reflux. Surgical myotomy was originally performed via thoracotomy with good to excellent results in 60-94\% of patients followed for 1-36 years [11]. This intervention evolved to be performed with a laparotomy approach, then a thoracoscopic approach, and finally via laparoscopy that has fallen in favor due to superior visualization of the gastroesophageal junction, the ability to add an antireflux procedure, decreased morbidity, shorter hospital stay, and faster recovery [103].

A cumulative good to excellent clinical response rate of $94 \%$ has been reported for laparoscopic myotomy over a short period of time. Studies on longterm outcome of myotomy are summarized in Table 2. The major disadvantages of myotomy are incomplete myotomy and the possibility of significant GERD. Table 2 also shows the rate of developing GERD after myotomy in the most valuable studies reported. In a double-blind randomized trial, Richards et al. reported abnormal acid exposure on $\mathrm{pH}$ monitoring in $47 \%$ of patients without an anti-reflux procedure compared to $9 \%$ of patients who had a Dor fundoplication [104]. While a concomitant anti-reflux procedure is recommended [105], the type of fundoplication (Dor vs. posterior Toupet) remains controversial with recent meta-analysis showing significantly higher recurrence rate of clinical regurgitation and pathological acid reflux in the Dor fundoplication group [106].

Rebecchi et al. reported similar long-term reflux control in patients who received a Heller myotomy plus floppyNissen versus Dor fundoplication; however, those who underwent Nissen fundoplication experienced more recurrence of dysphagia [107]. Subsequently, multiple recent randomized controlled trials comparing Heller myotomy in conjunction with a Dor versus Toupet fundoplication showed significant improvement in both dysphagia and regurgitation symptoms regardless of the type of partial fundoplication with dramatic improvements in Eckardt scores $[108,109]$. Patients undergoing Toupet fundoplication did have significantly better relative improvements in the EORTC QLQ-OES18 (functional scale), but otherwise 
Table 2 Long-term result of laparoscopic myotomy with fundoplications

\begin{tabular}{|c|c|c|c|c|c|c|}
\hline Study & Method & Method of surgery & $\begin{array}{l}\text { Number of patients } \\
\text { enrolled }\end{array}$ & Length of follow-up & $\begin{array}{l}\text { Good to excellent } \\
\text { response }\end{array}$ & $\begin{array}{l}\text { GERD }^{a} \\
\text { complication }\end{array}$ \\
\hline Bessell et al. [126] & Prospective & Laparoscopic HM $^{b}$ & 167 & 5 years & $77 \%$ & Not mentioned \\
\hline Vella et al. [99], & Retrospectivecohort & $\begin{array}{l}88 \% \text { Laparoscopic } \\
\text { and } 12 \% \text { open HM }\end{array}$ & 73 & 6 years & $57 \%$ & $36 \%$ \\
\hline Dang et al. [127] & Retrospective & $\begin{array}{l}81 \% \text { Laparoscopic } \\
\text { and } 9 \% \text { open HM }\end{array}$ & 22 & 3 years & $76 \%$ & Not mentioned \\
\hline Raiser et al. [128] & Retrospective & $\begin{array}{l}\text { Laparoscopic or } \\
\text { thoracoscopic HM }\end{array}$ & 35 & $1-4$ years & $97 \%$ & Not mentioned \\
\hline Hunt et al. [129] & Retrospective & Laparoscopic HM & 70 & 2.9 years & $81 \%$ & $4.5 \%$ \\
\hline Frantzides et al. [130] & Retrospective & Laparoscopic HM & 53 & 3 years & $92 \%$ & $9 \%$ \\
\hline Zaninotto et al. [131] & Prospective & Laparoscopic HM & 100 & $2 y$ & $92 \%$ & $7 \%$ \\
\hline
\end{tabular}

${ }^{\mathrm{a} G E R D}$ Gastroesophageal reflux disease; ${ }^{\mathrm{b}} \mathrm{HM}$ Heller myotomy

no differences between the two anti-reflux repairs were noted [109]. Thus, the optimum fundoplication procedure after HM for achalasia remains controversial, but given the likelihood of reflux symptoms after myotomy despite added fundoplication, proton pump inhibitor (PPI) therapy may be indicated in those who complain of heartburn [5].

Possible treatment options after a failed myotomy include PD or a repeat surgical myotomy. A study of untreated achalasia patients and patients with failed myotomy reports no increased risk of perforation with performing PD after Heller myotomy. However, this study also indicates that despite lower LES pressure, patients undergoing PD after failed myotomy do not do as well as untreated cases [110]. Finally, laparoscopic surgery used to be performed only on patients who relapsed after graded PD; however, PD and surgical myotomy are now offered as initial therapy for patients who are at low surgical risk. Studies show best outcomes after PD in patients older than 40 years, women, those with narrow esophageal diameter, and those with a type II pattern on HRM $[63,69,99,111,112]$, while surgery may be indicated as the first line therapy for patients with tortuous esophagus, esophageal diverticula, or previous surgery on the gastroesophageal junction.

\section{Per-oral endoscopic myotomy}

Per-oral endoscopic myotomy (POEM) is an endoscopic approach to esophagomyotomy that was first reported in porcine models by Pasricha et al. [79] and then in humans by Inoue et al. [113]. Since its introduction in humans in 2010, this novel approach has been increasingly used at centers worldwide. POEM involves an esophageal mucosal incision (approximately $10 \mathrm{~cm}$ proximal to esophagogastric junction) followed by creation of a submucosal tunnel and dissection of the muscle fibers beginning at $3 \mathrm{~cm}$ distal to the mucosal entry site and extending $2 \mathrm{~cm}$ into the cardia [114]. Since it is essential to prevent an inadequate myotomy, extension of the submucosal tunnel beyond the LES into the cardia is confirmed via a retroflexed view with visualization of the blue dye (used in the submucosal injection). The incision is subsequently closed with hemostatic clips or endoscopic suturing [114]. This procedure is technically demanding and requires a certain level of training and expertise. However, treatment success has been reported as high as $90 \%$ with significant decreases in LES pressure, decreased Eckardt scores, and improved quality of life measurements with low complication rates [115]. The main complication is GERD that has been reported to occur in approximately $12 \%$ of patients. Other rare potential complications include delayed bleeding, pneumomediastinum, pneumothorax, pneumoperitoneum, and mucosal flap perforation [114]. POEM appears to be a promising intervention; however, current data is limited by small study numbers and short-term follow-up.

\section{Comparison of the procedures}

Several randomized trials suggest that pneumatic dilation is more effective than botulinum toxin $[2,116,117]$. Our study, which was one of the largest studies comparing the outcome of two therapies, suggested that both therapies are effective at 1 month, but PD results in significantly better symptom improvement at 12 months compared with BT (70 \% vs. $32 \%$ respectively) [2]. These findings indicate that botulinum toxin is inferior to pneumatic dilation for sustained symptom relief [118]. A study on cost-effectiveness of treatments also suggests that in the long-term, PD is a more costeffective treatment for achalasia compared to BT [119].

Comparison of PD and HM also shows that there is no difference in the early outcome of these treatments, and the success rate of both methods decreases over time (90 \% vs. $89 \%$ respectively at 6 months, to $44 \% v s$. $56 \%$ at 6 years) [99]. Studies also suggest that laparoscopic myotomy is not a cost-effective therapy as the initial cost is too high [119]. However, HM has improved 
cost-effectiveness and the difference between the two treatment modalities decreases if the durability of HM is $>10$ years given the likelihood of necessary repeated PD treatments [120]. Laparoscopic HM is an effective treatment modality in patients with achalasia who have failed to respond to $\mathrm{PD}$, as the 10 -year remission rate in these patients following myotomy is shown to be $77 \%$ compared to $72 \%$ and $45 \%$ in patients "successfully" treated with a single PD and patients undergoing several dilations respectively [121]. Overall, HM is the more durable treatment for achalasia, but PD is more cost-effective. A recent randomized trial comparing $\mathrm{HM}$ to $\mathrm{PD}$ showed equivalent treatment outcome after two years of follow up in 201 patients with achalasia [111]. Subsequently, a comparative study between POEM and HM showed that both interventions resulted in similar symptom and physiology improvement, but POEM resulted in shorter operative times and shorter hospitalizations [122].

A proposed algorithm for the management of patients with achalasia is depicted in Fig. 5. The choice of initial therapy should be guided by patients' age, gender, preference, and local institutional expertise. Surgical myotomy and PD remain the key treatment options for patients.
When deciding on myotomy vs $\mathrm{PD}$, it is important to consider the complications, durability, and costeffectiveness, as well as the experience of the surgeons and gastroenterologists. Botulinum toxin therapy is recommended for patients who are not surgical candidates or are high-risk, and pharmacologic therapy is reserved for patients who cannot undergo definitive treatment or have failed botulinum toxin injections.

\section{Conclusions}

Achalasia is a motor disorder of the esophagus characterized by dysphagia, regurgitation, and chest pain. Although it cannot be permanently cured, excellent palliation is available in over $90 \%$ of patients. As a result of the advances in pneumatic dilation and laparoscopic Heller myotomy, most patients with achalasia can now choose between these two treatments. The injection of botulinum toxin endoscopically into the LES is usually reserved for elderly, or patients who are not candidates for pneumatic dilation or surgery. In patients unresponsive to graded pneumatic dilation, esophageal myotomy via the laparoscopic method should be performed.

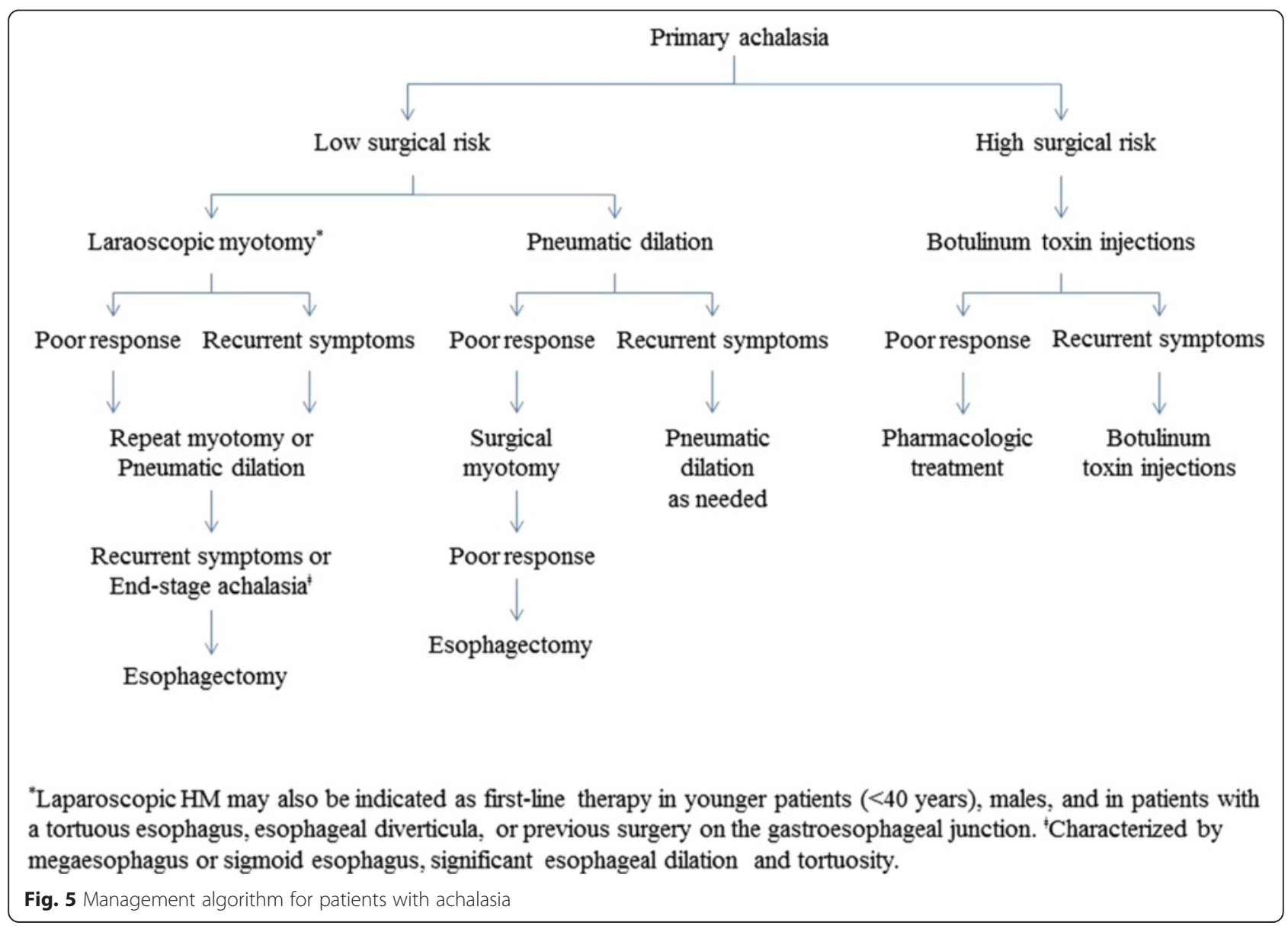




\section{Competing interests}

The authors declare that they have no competing interests.

\section{Authors' contributions}

DP, HK, and JS drafted the manuscript. All authors read and approved the final manuscript.

\section{Disclosures}

No COI with this project.

\section{Author details}

${ }^{1}$ Department of Internal Medicine, Nashville, TN, USA. ${ }^{2}$ Division of Gastroenterology, Hepatology and Nutrition, Vanderbilt University Medical Center, Nashville, TN, USA.

\section{Received: 6 January 2015 Accepted: 6 July 2015}

Published online: 22 July 2015

\section{References}

1. Vaezi MF. Achalasia: diagnosis and management. Semin Gastrointest Dis. 1999;10:103-12.

2. Vaezi MF, Richter JE, Wilcox CM, Schroeder PL, Birgisson S, Slaughter RL, et al. Botulinum toxin versus pneumatic dilatation in the treatment of achalasia: a randomised trial. Gut. 1999;44:231-9.

3. Park W, Vaezi MF. Etiology and pathogenesis of achalasia: the current understanding. Am J Gastroenterol. 2005;100:1404-14.

4. Mikaeli J, Farrokhi F, Bishehsari F, Mahdavinia M, Malekzadeh R. Gender effect on clinical features of achalasia: a prospective study. BMC Gastroenterol. 2006;6:12.

5. Vaezi MF, Pandolfino JE, Vela MF. ACG clinical guideline: diagnosis and management of achalasia. Am J Gastroenterol. 2013;108:1238-49. quiz 1250.

6. Sadowski DC, Ackah F, Jiang B, Svenson LW. Achalasia: incidence, prevalence and survival. A population-based study. Neurogastroenterol Motil. 2010;22:e256-61.

7. O'Neill OM, Johnston BT, Coleman HG. Achalasia: a review of clinical diagnosis, epidemiology, treatment and outcomes. World J Gastroenterol. 2013;19:5806-12.

8. Vela MF, Vaezi MF. Cost-assessment of alternative management strategies for achalasia. Expert Opin Pharmacother. 2003;4:2019-25.

9. Birgisson S, Richter JE. Achalasia: what's new in diagnosis and treatment? Dig Dis. 1997;15 Suppl 1:1-27.

10. Prakash C, Clouse RE. Esophageal motor disorders. Curr Opin Gastroenterol. 1999;15:339-46.

11. Vaezi MF, Richter JE. Current therapies for achalasia: comparison and efficacy. J Clin Gastroenterol. 1998;27:21-35.

12. Katz PO, Gerson LB, Vela MF. Guidelines for the diagnosis and management of gastroesophageal reflux disease. Am J Gastroenterol. 2013;108:308-28. quiz 329.

13. Clouse RE, Abramson BK, Todorczuk JR. Achalasia in the elderly. Effects of aging on clinical presentation and outcome. Dig Dis Sci. 1991;36:225-8.

14. d'Alteroche L, Oung C, Fourquet F, Picon L, Lagasse JP, Metman EH. Evolution of clinical and radiological features at diagnosis of achalasia during a 19-year period in central France. Eur J Gastroenterol Hepatol. 2001;13:121-6.

15. Rakita S, Bloomston M, Villadolid D, Thometz D, Boe B, Rosemurgy A. Age affects presenting symptoms of achalasia and outcomes after myotomy. Am Surg. 2005;71:424-9.

16. Sinan H, Tatum RP, Soares RV, Martin AV, Pellegrini CA, Oelschlager BK. Prevalence of respiratory symptoms in patients with achalasia. Dis Esophagus. 2011;24:224-8.

17. Spechler SJ, Souza RF, Rosenberg SJ, Ruben RA, Goyal RK. Heartburn in patients with achalasia. Gut. 1995;37:305-8.

18. Massey BT, Hogan WJ, Dodds WJ, Dantas RO. Alteration of the upper esophageal sphincter belch reflex in patients with achalasia. Gastroenterology. 1992;103:1574-9.

19. Mearin F, Mourelle M, Guarner F, Salas A, Riveros-Moreno V, Moncada S, et al. Patients with achalasia lack nitric oxide synthase in the gastrooesophageal junction. Eur J Clin Investig. 1993;23:724-8.

20. Cassella RR, Brown Jr AL, Sayre GP, Ellis Jr FH. Achalasia of the Esophagus: Pathologic and Etiologic Considerations. Ann Surg. 1964;160:474-87.
21. Higgs B, Kerr FW, Ellis Jr FH. The experimental production of esophageal achalasia by electrolytic lesions in the medulla. J Thorac Cardiovasc Surg. 1965;50:613-25.

22. Atkinson M, Ogilvie AL, Robertson CS, Smart HL. Vagal function in achalasia of the cardia. Q J Med. 1987;63:297-303.

23. Eckardt VF, Krause J, Bolle D. Gastrointestinal transit and gastric acid secretion in patients with achalasia. Dig Dis Sci. 1989;34:665-71.

24. Khajanchee YS, VanAndel R, Jobe BA, Barra MJ, Hansen PD, Swanstrom LL. Electrical stimulation of the vagus nerve restores motility in an animal model of achalasia. J Gastrointest Surg. 2003;7:843-9. discussion 849.

25. Holloway RH, Dodds WJ, Helm JF, Hogan WJ, Dent J, Arndorfer RC. Integrity of cholinergic innervation to the lower esophageal sphincter in achalasia. Gastroenterology. 1986;90:924-9.

26. Greaves RR, Mulcahy HE, Patchett SE, Gorard DA, Fairclough PD, Alstead EM, et al. Early experience with intrasphincteric botulinum toxin in the treatment of achalasia. Aliment Pharmacol Ther. 1999;13:1221-5.

27. Dodds WJ, Dent J, Hogan WJ, Patel GK, Toouli J, Arndorfer RC. Paradoxical lower esophageal sphincter contraction induced by cholecystokininoctapeptide in patients with achalasia. Gastroenterology. 1981;80:327-33.

28. Goldblum JR, Whyte RI, Orringer MB, Appelman HD. Achalasia. A morphologic study of 42 resected specimens. Am J Surg Pathol. 1994;18:327-37.

29. Goldblum JR, Rice TW, Richter JE. Histopathologic features in esophagomyotomy specimens from patients with achalasia. Gastroenterology. 1996;111:648-54.

30. Frieling T, Berges W, Borchard F, Lubke HJ, Enck P, Wienbeck M. Family occurrence of achalasia and diffuse spasm of the oesophagus. Gut. 1988;29:1595-602

31. Stein DT, Knauer CM. Achalasia in monozygotic twins. Dig Dis Sci. 1982;27:636-40.

32. Annese V, Napolitano G, Minervini MM, Perri F, Ciavarella G, Di Giorgio G, et al. Family occurrence of achalasia. J Clin Gastroenterol. 1995;20:329-30.

33. Bosher LP, Shaw A. Achalasia in siblings. Clinical and genetic aspects. Am J Dis Child. 1981;135:709-10.

34. Hallal C, Kieling CO, Nunes DL, Ferreira CT, Peterson G, Barros SG, et al. Diagnosis, misdiagnosis, and associated diseases of achalasia in children and adolescents: a twelve-year single center experience. Pediatr Surg Int. 2012;28:1211-7.

35. Tullio-Pelet A, Salomon R, Hadj-Rabia S, Mugnier C, de Laet MH, Chaouachi $B$, et al. Mutant WD-repeat protein in triple-A syndrome. Nat Genet. 2000;26:332-5

36. Moore SW. Down syndrome and the enteric nervous system. Pediatr Surg Int. 2008:24:873-83.

37. Shteyer E, Edvardson S, Wynia-Smith SL, Pierri CL, Zangen T, Hashavya S, et al. Truncating mutation in the nitric oxide synthase 1 gene is associated with infantile achalasia. Gastroenterology. 2015;148:533-6. e534.

38. Paladini F, Cocco E, Cascino I, Belfiore F, Badiali D, Piretta L, et al. Age-dependent association of idiopathic achalasia with vasoactive intestinal peptide receptor 1 gene. Neurogastroenterol Motil. 2009:21:597-602.

39. de Leon AR, de la Serna JP, Santiago JL, Sevilla C, Fernandez-Arquero M, de la Concha EG, et al. Association between idiopathic achalasia and IL23R gene. Neurogastroenterol Motil. 2010;22:734-8. e218.

40. Nunez C, Garcia-Gonzalez MA, Santiago JL, Benito MS, Mearin F, de la Concha EG, et al. Association of IL10 promoter polymorphisms with idiopathic achalasia. Hum Immunol. 2011;72:749-52.

41. Evsyutina $\mathrm{Y}$, Trukhmanov AS, Ivashkin VT. Family case of achalasia cardia: case report and review of literature. World J Gastroenterol. 2014;20:1114-8.

42. Latiano A, Palmieri O, Bossa F, Latiano T, Corritore G, De Santo E, et al. Impact of genetic polymorphisms on the pathogenesis of idiopathic achalasia: Association with IL33 gene variant. Hum Immunol. 2014;75:364-9.

43. Santiago JL, Martinez A, Benito MS, Ruiz de Leon A, Mendoza JL, Fernandez-Arquero M, et al. Gender-specific association of the PTPN22 C1858T polymorphism with achalasia. Hum Immunol. 2007;68:867-70.

44. Jones DB, Mayberry JF, Rhodes J, Munro J. Preliminary report of an association between measles virus and achalasia. J Clin Pathol. 1983:36:655-7.

45. Robertson CS, Martin BA, Atkinson M. Varicella-zoster virus DNA in the oesophageal myenteric plexus in achalasia. Gut. 1993;34:299-302.

46. Niwamoto H, Okamoto E, Fujimoto J, Takeuchi M, Furuyama J, Yamamoto Y. Are human herpes viruses or measles virus associated with esophageal achalasia? Dig Dis Sci. 1995;40:859-64. 
47. Birgisson S, Galinski MS, Goldblum JR, Rice TW, Richter JE. Achalasia is not associated with measles or known herpes and human papilloma viruses. Dig Dis Sci. 1997:42:300-6.

48. Castagliuolo I, Brun P, Costantini M, Rizzetto C, Palu G, Costantino M, et al. Esophageal achalasia: is the herpes simplex virus really innocent? J Gastrointest Surg. 2004;8:24-30. discussion 30.

49. Facco M, Brun P, Baesso I, Costantini M, Rizzetto C, Berto A, et al. T cells in the myenteric plexus of achalasia patients show a skewed TCR repertoire and react to HSV-1 antigens. Am J Gastroenterol. 2008;103:1598-609.

50. Boeckxstaens GE. Achalasia: virus-induced euthanasia of neurons? Am J Gastroenterol. 2008;103:1610-2.

51. Storch WB, Eckardt VF, Wienbeck M, Eberl T, Auer PG, Hecker A, et al. Autoantibodies to Auerbach's plexus in achalasia. Cell Mol Biol. 1995;41:1033-8.

52. Verne GN, Sallustio JE, Eaker EY. Anti-myenteric neuronal antibodies in patients with achalasia. A prospective study. Dig Dis Sci. 1997;42:307-13.

53. Moses PL, Ellis LM, Anees MR, Ho W, Rothstein Rl, Meddings JB, et al. Antineuronal antibodies in idiopathic achalasia and gastro-oesophageal reflux disease. Gut. 2003;52:629-36.

54. Booy JD, Takata J, Tomlinson G, Urbach DR. The prevalence of autoimmune disease in patients with esophageal achalasia. Dis Esophagus. 2012;25:209-13.

55. Raymond L, Lach B, Shamji FM. Inflammatory aetiology of primary oesophageal achalasia: an immunohistochemical and ultrastructural study of Auerbach's plexus. Histopathology. 1999;35:445-53.

56. Clark SB, Rice TW, Tubbs RR, Richter JE, Goldblum JR. The nature of the myenteric infiltrate in achalasia: an immunohistochemical analysis. Am J Surg Pathol. 2000;24:1153-8.

57. Wong RK, Maydonovitch CL, Metz SJ, Baker Jr JR. Significant DQw1 association in achalasia. Dig Dis Sci. 1989;34:349-52.

58. De la Concha EG, Fernandez-Arquero M, Mendoza JL, Conejero L, Figueredo MA, Perez de la Serna J, et al. Contribution of HLA class II genes to susceptibility in achalasia. Tissue Antigens. 1998:52:381-4.

59. Verne GN, Hahn AB, Pineau BC, Hoffman BJ, Wojciechowski BW, Wu WC. Association of HLA-DR and -DQ alleles with idiopathic achalasia. Gastroenterology. 1999;117:26-31.

60. Ruiz-de-Leon A, Mendoza J, Sevilla-Mantilla C, Fernandez AM, Perez-de-laSerna J, Gonzalez VA, et al. Myenteric antiplexus antibodies and class II HLA in achalasia. Dig Dis Sci. 2002;47:15-9.

61. Ghoshal UC, Daschakraborty SB, Singh R. Pathogenesis of achalasia cardia. World J Gastroenterol. 2012;18:3050-7.

62. Vantrappen $G$, Vangoidsenhoven $G E$, Verbeke $S$, Vandenberghe $G$, Vanderbroucke J. Manometric Studies in Achalasia of the Cardia, before and after Pneumatic Dilations. Gastroenterology. 1963;45:317-25.

63. Pandolfino JE, Kwiatek MA, Nealis T, Bulsiewicz W, Post J, Kahrilas PJ. Achalasia: a new clinically relevant classification by high-resolution manometry. Gastroenterology. 2008;135:1526-33.

64. Ghosh SK, Pandolfino JE, Rice J, Clarke JO, Kwiatek M, Kahrilas PJ. Impaired deglutitive EGJ relaxation in clinical esophageal manometry: a quantitative analysis of 400 patients and 75 controls. Am J Physiol Gastrointest Liver Physiol. 2007;293:G878-85.

65. Salvador R, Costantini M, Zaninotto G, Morbin T, Rizzetto C, Zanatta L, et al. The preoperative manometric pattern predicts the outcome of surgical treatment for esophageal achalasia. J Gastrointest Surg. 2010;14:1635-45.

66. Pratap N, Reddy DN. Can achalasia subtyping by high-resolution manometry predict the therapeutic outcome of pneumatic balloon dilatation?: author's reply. J Neurogastroenterol Motil. 2011;17:205.

67. Vantrappen G, Hellemans J, Deloof W, Valembois P, Vandenbroucke J. Treatment of achalasia with pneumatic dilatations. Gut. 1971;12:268-75.

68. de Oliveira JM, Birgisson S, Doinoff C, Einstein D, Herts B, Davros W, et al. Timed barium swallow: a simple technique for evaluating esophageal emptying in patients with achalasia. AJR Am J Roentgenol. 1997;169:473-9.

69. Vaezi MF, Baker ME, Achkar E, Richter JE. Timed barium oesophagram: bette predictor of long term success after pneumatic dilation in achalasia than symptom assessment. Gut. 2002;50:765-70.

70. Vaezi MF, Baker ME, Richter JE. Assessment of esophageal emptying post-pneumatic dilation: use of the timed barium esophagram. Am J Gastroenterol. 1999;94:1802-7.

71. Andersson M, Lundell L, Kostic S, Ruth M, Lonroth H, Kjellin A, et al. Evaluation of the response to treatment in patients with idiopathic achalasia by the timed barium esophagogram: results from a randomized clinical trial. Dis Esophagus. 2009;22:264-73.

72. Tucker HJ, Snape Jr WJ, Cohen S. Achalasia secondary to carcinoma: manometric and clinical features. Ann Intern Med. 1978;89:315-8.

73. Kahrilas PJ, Kishk SM, Helm JF, Dodds WJ, Harig JM, Hogan WJ. Comparison of pseudoachalasia and achalasia. Am J Med. 1987;82:439-46.

74. Mittal RK, Kassab G, Puckett JL, Liu J. Hypertrophy of the muscularis propria of the lower esophageal sphincter and the body of the esophagus in patients with primary motility disorders of the esophagus. Am J Gastroenterol. 2003;98:1705-12.

75. Rodrigo S, Abboud G, Oh D, DeMeester SR, Hagen J, Lipham J, et al. High intraepithelial eosinophil counts in esophageal squamous epithelium are not specific for eosinophilic esophagitis in adults. Am J Gastroenterol. 2008;103:435-42.

76. Sandler RS, Nyren O, Ekbom A, Eisen GM, Yuen J, Josefsson S. The risk of esophageal cancer in patients with achalasia. A population-based study. JAMA. 1995:274:1359-62

77. de Oliveira RB, Rezende Filho J, Dantas RO, lazigi N. The spectrum of esophageal motor disorders in Chagas' disease. Am J Gastroenterol. 1995;90:1119-24

78. Zhao JG, Li YD, Cheng YS, Li MH, Chen NW, Chen WX, et al. Long-term safety and outcome of a temporary self-expanding metallic stent for achalasia: a prospective study with a 13-year single-center experience. Eur Radiol. 2009;19:1973-80.

79. Pasricha PJ, Hawari R, Ahmed I, Chen J, Cotton PB, Hawes RH, et al. Submucosal endoscopic esophageal myotomy: a novel experimental approach for the treatment of achalasia. Endoscopy. 2007:39:761-4.

80. Minami H, Inoue H, Haji A, Isomoto H, Urabe S, Hashiguchi K, et al. Per-oral endoscopic myotomy: Emerging indications and evolving techniques. Dig Endosc. 2015;27:175-81.

81. Annese V, Bassotti G. Non-surgical treatment of esophageal achalasia. World J Gastroenterol. 2006;12:5763-6.

82. Pehlivanov N, Pasricha PJ. Achalasia: botox, dilatation or laparoscopic surgery in 2006. Neurogastroenterol Motil. 2006;18:799-804.

83. Gelfond $M$, Rozen P, Gilat T. Isosorbide dinitrate and nifedipine treatment of achalasia: a clinical, manometric and radionuclide evaluation. Gastroenterology. 1982;83:963-9.

84. Bortolotti M, Coccia G, Brunelli F, Sarti P, Mazza M, Bagnato F, et al. Isosorbide dinitrate or nifedipine: which is preferable in the medical therapy of achalasia? Ital J Gastroenterol. 1994;26:379-82.

85. Bortolotti M, Mari C, Lopilato C, Porrazzo G, Miglioli M. Effects of sildenafil on esophageal motility of patients with idiopathic achalasia. Gastroenterology. 2000;118:253-7.

86. Pasricha PJ, Ravich WJ, Hendrix TR, Sostre S, Jones B, Kalloo AN. Treatment of achalasia with intrasphincteric injection of botulinum toxin. A Pilot Trial Ann Intern Med. 1994;121:590-1.

87. Pasricha PJ, Ravich WJ, Hendrix TR, Sostre S, Jones B, Kalloo AN Intrasphincteric botulinum toxin for the treatment of achalasia. N Engl J Med. 1995;332:774-8

88. Chuah SK, Chiu CH, Tai WC, Lee JH, Lu HI, Changchien CS, et al. Current status in the treatment options for esophageal achalasia. World J Gastroenterol. 2013;19:5421-9.

89. Patti MG, Feo CV, Arcerito M, De Pinto M, Tamburini A, Diener U, et al. Effects of previous treatment on results of laparoscopic Heller myotomy for achalasia. Dig Dis Sci. 1999:44:2270-6.

90. Horgan S, Hudda K, Eubanks T, McAllister J, Pellegrini CA. Does botulinum toxin injection make esophagomyotomy a more difficult operation? Surg Endosc. 1999:13:576-9.

91. Smith CD, Stival A, Howell DL, Swafford V. Endoscopic therapy for achalasia before Heller myotomy results in worse outcomes than heller myotomy alone. Ann Surg. 2006;243:579-84. discussion 584-576.

92. Fishman VM, Parkman HP, Schiano TD, Hills C, Dabezies MA, Cohen S, et al, Symptomatic improvement in achalasia after botulinum toxin injection of the lower esophageal sphincter. Am J Gastroenterol. 1996;91:1724-30.

93. Annese V, Bassotti G, Coccia G, Dinelli M, D'Onofrio V, Gatto G, et al. A multicentre randomised study of intrasphincteric botulinum toxin in patients with oesophageal achalasia. GISMAD Achalasia Study Group Gut. 2000:46:597-600.

94. Pasricha PJ, Rai R, Ravich WJ, Hendrix TR, Kalloo AN. Botulinum toxin for achalasia: long-term outcome and predictors of response. Gastroenterology. 1996;110:1410-5. 
95. Eckardt VF, Aignherr C, Bernhard G. Predictors of outcome in patients with achalasia treated by pneumatic dilation. Gastroenterology. 1992;103:1732-8.

96. Achkar E. Achalasia. Gastroenterologist. 1995;3:273-88.

97. Richter JE. Modern management of achalasia. Curr Treat Options gastroenterol. 2005;8:275-83.

98. Eckardt AJ, Eckardt VF. Treatment and surveillance strategies in achalasia: an update. Nat Rev Gastroenterol Hepatol. 2011;8:311-9.

99. Vela MF, Richter JE, Khandwala F, Blackstone EH, Wachsberger D, Baker ME, et al. The long-term efficacy of pneumatic dilatation and Heller myotomy for the treatment of achalasia. Clin Gastroenterol Hepatol. 2006;4:580-7.

100. Torbey CF, Achkar E, Rice TW, Baker M, Richter JE. Long-term outcome of achalasia treatment: the need for closer follow-up. J Clin Gastroenterol. 1999;28:125-30.

101. Karamanolis G, Sgouros S, Karatzias G, Papadopoulou E, Vasiliadis K, Stefanidis $\mathrm{G}$, et al. Long-term outcome of pneumatic dilation in the treatment of achalasia. Am J Gastroenterol. 2005;100:270-4.

102. Vaezi MF. Quantitative methods to determine efficacy of treatment in achalasia. Gastrointest Endosc Clin N Am. 2001;11:409-24. viii-ix.

103. Ali A, Pellegrini CA. Laparoscopic myotomy: technique and efficacy in treating achalasia. Gastrointest Endosc Clin N Am. 2001;11:347-58. vii.

104. Richards WO, Torquati A, Holzman MD, Khaitan L, Byrne D, Lutfi R, et al. Heller myotomy versus Heller myotomy with Dor fundoplication for achalasia: a prospective randomized double-blind clinical trial. Ann Surg. 2004;240:405-12. discussion 412-405.

105. Stefanidis D, Richardson W, Farrell TM, Kohn GP, Augenstein V, Fanelli RD, et al. SAGES guidelines for the surgical treatment of esophageal achalasia. Surg Endosc. 2012;26:296-311.

106. Wei MT, He YZ, Deng XB, Zhang YC, Yang TH, Jin CW, et al. Is Dor fundoplication optimum after laparoscopic Heller myotomy for achalasia? A meta-analysis. World J Gastroenterol. 2013;19:7804-12.

107. Rebecchi F, Giaccone C, Farinella E, Campaci R, Morino M. Randomized controlled trial of laparoscopic Heller myotomy plus Dor fundoplication versus Nissen fundoplication for achalasia: long-term results. Ann Surg. 2008;248:1023-30.

108. Rawlings A, Soper NJ, Oelschlager B, Swanstrom L, Matthews BD, Pellegrini C, et al. Laparoscopic Dor versus Toupet fundoplication following Heller myotomy for achalasia: results of a multicenter, prospective, randomizedcontrolled trial. Surg Endosc. 2012;26:18-26.

109. Kumagai K, Kjellin A, Tsai JA, Thorell A, Granqvist S, Lundell L, et al. Toupet versus Dor as a procedure to prevent reflux after cardiomyotomy for achalasia: results of a randomised clinical trial. Int J Surg. 2014;12:673-80.

110. Guardino JM, Vela MF, Connor JT, Richter JE. Pneumatic dilation for the treatment of achalasia in untreated patients and patients with failed Heller myotomy. J Clin Gastroenterol. 2004;38:855-60.

111. Boeckxstaens GE, Annese V, des Varannes SB, Chaussade S, Costantini M, Cuttitta A, et al. Pneumatic dilation versus laparoscopic Heller's myotomy for idiopathic achalasia. N Engl J Med. 2011;364:1807-16.

112. Rohof WO, Salvador R, Annese V, Bruley des Varannes S, Chaussade S, Costantini $\mathrm{M}$, et al. Outcomes of treatment for achalasia depend on manometric subtype. Gastroenterology. 2013;144:718-25. quiz e713-714.

113. Inoue $H$, Minami $H$, Kobayashi $Y$, Sato $Y$, Kaga $M$, Suzuki $M$, et al. Peroral endoscopic myotomy (POEM) for esophageal achalasia. Endoscopy. 2010;42:265-71.

114. Kumta NA, Mehta S, Kedia P, Weaver K, Sharaiha RZ, Fukami N, et al. Peroral endoscopic myotomy: establishing a new program. Clin Endosc 2014;47:389-97.

115. Ling TS, Guo HM, Yang T, Peng CY, Zou XP, Shi RH. Effectiveness of peroral endoscopic myotomy in the treatment of achalasia: a pilot trial in Chinese Han population with a minimum of one-year follow-up. J Dig Dis. 2014;15:352-8

116. Annese V, Basciani M, Perri F, Lombardi G, Frusciante V, Simone P, et al. Controlled trial of botulinum toxin injection versus placebo and pneumatic dilation in achalasia. Gastroenterology. 1996;111:1418-24.

117. Mikaeli J, Fazel A, Montazeri G, Yaghoobi M, Malekzadeh R. Randomized controlled trial comparing botulinum toxin injection to pneumatic dilatation for the treatment of achalasia. Aliment Pharmacol Ther. 2001;15:1389-96.

118. Leyden JE, Moss AC, MacMathuna P. Endoscopic pneumatic dilation versus botulinum toxin injection in the management of primary achalasia. Cochrane Database Syst Rev. 2014;12, CD005046.

119. O'Connor JB, Singer ME, Imperiale TF, Vaezi MF, Richter JE. The cost-effectiveness of treatment strategies for achalasia. Dig Dis Sci. 2002;47:1516-25.
120. Karanicolas PJ, Smith SE, Inculet RI, Malthaner RA, Reynolds RP, Goeree R, et al. The cost of laparoscopic myotomy versus pneumatic dilatation for esophageal achalasia. Surg Endosc. 2007;21:1198-206.

121. Gockel I, Junginger T, Bernhard G, Eckardt VF. Heller myotomy for failed pneumatic dilation in achalasia: how effective is it? Ann Surg. 2004;239:371-7.

122. Bhayani NH, Kurian AA, Dunst CM, Sharata AM, Rieder E, Swanstrom LL. A comparative study on comprehensive, objective outcomes of laparoscopic Heller myotomy with per-oral endoscopic myotomy (POEM) for achalasia. Ann Surg. 2014;259:1098-103.

123. Gordon JM, Eaker EY. Prospective study of esophageal botulinum toxin injection in high-risk achalasia patients. Am J Gastroenterol. 1997;92:1812-7.

124. Martinek J, Siroky M, Plottova Z, Bures J, Hep A, Spicak J. Treatment of patients with achalasia with botulinum toxin: a multicenter prospective cohort study. Dis Esophagus. 2003;16:204-9.

125. Zaninotto G, Annese V, Costantini M, Del Genio A, Costantino M, Epifani M, et al. Randomized controlled trial of botulinum toxin versus laparoscopic heller myotomy for esophageal achalasia. Ann Surg. 2004;239:364-70.

126. Bessell JR, Lally CJ, Schloithe A, Jamieson GG, Devitt PG, Watson DI. Laparoscopic cardiomyotomy for achalasia: long-term outcomes. ANZ J Surg. 2006;76:558-62.

127. Dang Y, Mercer D. Treatment of esophageal achalasia with Heller myotomy: retrospective evaluation of patient satisfaction and disease-specific quality of life. Can J Surg J Canadien de chirurgie. 2006:49:267-71.

128. Raiser F, Perdikis G, Hinder RA, Swanstrom LL, Filipi CJ, McBride PJ, et al. Heller myotomy via minimal-access surgery. An evaluation of antireflux procedures. Arch Surg. 1996;131:593-7. discussion 597-598.

129. Hunt DR, Wills VL. Laparoscopic Heller myotomy for achalasia. Aust N Z J Surg. 2000;70:582-6.

130. Frantzides CT, Moore RE, Carlson MA, Madan AK, Zografakis JG, Keshavarzian A, et al. Minimally invasive surgery for achalasia: a 10-year experience. J Gastrointest Surg. 2004;8:18-23.

131. Zaninotto G, Costantini M, Molena D, Buin F, Carta A, Nicoletti L, et al. Treatment of esophageal achalasia with laparoscopic Heller myotomy and Dor partial anterior fundoplication: prospective evaluation of 100 consecutive patients. J Gastrointest Surg. 2000;4:282-9.

\section{Submit your next manuscript to BioMed Central and take full advantage of:}

- Convenient online submission

- Thorough peer review

- No space constraints or color figure charges

- Immediate publication on acceptance

- Inclusion in PubMed, CAS, Scopus and Google Scholar

- Research which is freely available for redistribution

Submit your manuscript at www.biomedcentral.com/submit 